\title{
Penerapan Finite State Automata pada Vending Machine dalam Melakukan Transaksi Pengembalian Buku di Perpustakaan
}

\author{
Refi Riduan Achmad ${ }^{1 *}$, Fahmi Fadillah Septiana², Nur Syamsi ${ }^{3}$ Bobby Suryo Prakoso ${ }^{4}$, Hafifah Bella \\ Novitasari $^{5}$ \\ ${ }^{1}$ Universitas Nusa Mandiri \\ ${ }^{2}$ Universitas Nusa Mandiri \\ ${ }^{3}$ UIN Sultan Aji Muhammad Idris Samarinda \\ ${ }^{4}$ Universitas Nusa Mandiri \\ ${ }^{5}$ STMIK Bani Saleh Bekasi \\ *14207020@nusamandiri.ac.id
}

\begin{abstract}
The Industrial Revolution 4.0 and Society 5.0 demand to continue to develop the fields of technology and human resources in all spheres of life. This study aims to combine technology and efforts to increase literacy, in this case discussing the application of finite automata on vending machines to facilitate book return transactions in the library. The research method is to describe Finite State Automata using Non-deterministic Finite Automata, design State Diagrams regarding features and interface design when the Vending Machine is implemented. The results showed that the use of Non-deterministic Finite Automata in the design of the Vending Machine for returning books in the library could facilitate book return transactions in the library.
\end{abstract}

Keywords: finite state automata, vending machine, library

\begin{abstract}
Abstrak
Revolusi Industri 4.0 dan Society 5.0 menuntut untuk terus mengembangkan bidang teknologi dan sumber daya manusia dalam seluruh ranah kehidupan. Penelitian ini bertujuan untuk memadukan antara teknologi dan upaya peningkatan literasi, dalam hal ini membahas tentang penerapan finite automata pada vending machine untuk mempermudah transaksi pengembalian buku di perpustakaan. Metode penelitian yakni melakukan penggambaran Finite State Automata menggunakan Non-deterministic Finite Automata, perancangan Diagram State mengenai fitur-fitur dan desain tampilan antarmuka saat Vending Machine diimplementasikan. Hasil penelitian menunjukkan bahwa penggunaan Non-deterministic Finite Automata pada desain Vending Machine pengembalian buku di perpustakaan dapat mempermudah transaksi pengembalian buku di perpustakaan.
\end{abstract}

Kata kunci: finite state automata, vending machine, perpustakaan

\section{Pendahuluan}

Revolusi industri 4.0 bukanlah sesuatu yang baru dibicarakan, namun dalam praktiknya ada begitu banyak sektor di Indonesia yang perlu diperhatikan dalam menerapkannya. Dalam mencari Sumber Daya Manusia (SDM) tidak hanya menguras waktu, namun juga biaya yang cukup banyak agar dapat memenuhi kebutuhan setiap instansi/lembaga untuk memberikan layanan terbaik bagi masyarakat secara cepat dengan memaksimalkan penggunaan teknologi.
Konsep revolusi industri 4.0 yang pertama kali diusung oleh Negara Jerman ini menggunakan kecerdasan buatan (artificial intelegency) dalam penerapannya.

Salah satu contoh teknologi revolusi industri 4.0 yang sudah banyak di kota-kota besar yang ada di Indonesia adalah penerapan automata pada vending machine [1].

Aplikasi simulasi vending machine yang dibuat berdasarkan desain diagram state menunjukkan bahwa finite automata dapat dirujuk menjadi dasar pengoperasiann untuk 
penerapan simulasi vending machine. Pengguna aplikasi memperoleh pengalaman dan pengetahuan tentang cara penggunaan vending machine jika memakai aplikasi ini.

Di Indonesia, vending machine mulai digunakan pada transaksi jual beli otomatis tanpa ada bantuan dari operator. Seorang konsumen bisa membeli dengan menyetorkan uang yang sesuai dengan harga barang yang tertera pada mesin. Tentu saja ini memberi keuntungan yang besar bagi distributor karena tidak lagi membayar orang lain untuk melayani konsumen. Vending machine seperti ini sudah sering ditemui di tempat-tempat umum seperti stasiun, bandara, mall, dll.

Selain pada sektor perdagangan, vending machine juga sudah digunakan dalam memudahkan masyarakat untuk melakukan transaksi dalam sektor perbankan. Vending machine dalam wujud Anjungan Tunai Mandiri atau biasa dikenal dengan ATM sudah ada sampai ke daerah-daerah. Vending machine satu ini sangat membantu masyarakat di seluruh penjuru Indonesia, transaksi penyetoran, penarikan, pembayaran, dan pemindahbukuan bisa dilakukan dengan mudah dan cepat. Meski semakin ke sini, keberadaan ATM juga sudah mulai tergantikan dengan penggunaan $e$-money dan ditemukannya aplikasi bank-bank terkait yang telah tersedia pada Playstore yang ada di handphone smartphone yang kini tak terpisahkan dari kehidupan sehari-hari manusia.

Kehadiran teknologi mestinya bisa memberi manfaat bagi manusia dalam berbagai hal. Bukan hanya dalam persoalan memberikan pelayanan yang mudah dan cepat untuk memanjakan manusia, tapi teknologi juga harus bisa digunakan dalam upaya peningkatan kualitas dan mutu SDM bangsa. Salah satunya dengan penerapan finite automata pada vending machine. Namun, sejauh ini vending machine masih banyak berkutat dalam percepatan regulasi dalam memberi pelayanan pada manusia, bukan pada upaya peningkatan mutu manusia. Sementara kita ketahui bersama bahwa salah satu masalah pokok yang dari dulu sampai sekarang mendapatkan perhatian khusus di negara ini adalah upaya peningkatan mutu
SDM. Hal tersebut tertuang dalam pembukaan UUD 1945 alinea ke-4 bahwa salah satu tujuan bangsa adalah untuk mencerdaskan kehidupan bangsa. Jadi, mestinya kehadiran teknologi bukan untuk semakin menghilangkan daya juang dan memperbodoh manusia, tapi justru sebaliknya.

Berbicara soal mutu SDM, maka di sini akan menyinggung cikal bakal munculnya Society 5.0 yang merupakan penyempurna Revolusi Industri 4.0. Dikatakan penyempurna, karena Revolusi Industri 4.0 hanya berfokus pada penggunaan mesin yang akan banyak menggantikan manusia dalam mengerjakan berbagai hal. Dengan adanya Society 5.0 yang diusung oleh Perdana Menteri Jepang Shinzo Abe ini menuntut adanya keselarasan antara kemajuan teknologi dan peningkatan mutu SDM bangsa.

Salah satu upaya yang dilakukan dalam upaya peningkatan mutu SDM adalah penggunaan teknologi dalam dunia pendidikan. Sebenarnya hal ini sudah sejak lama diupayakan, dapat dilihat dengan adanya program studi Teknologi Pendidikan di berbagai perguruan tinggi negeri di Indonesia. Namun demikian, kenyataanya dunia pendidikan bangsa ini tetap perlu mendapat perhatian dari ahli dari berbagai bidang keilmuan agar bisa menghasilkan mutu SDM yang mampu memberi manfaat dan sumbangsi yang berarti bagi bangsa dan negara serta mampu berdaya saing dengan negara lainnya.

Bangsa ini mengharapkan manusia unggul yang melek dengan penggunaan teknologi serta berwawasan luas dengan cara banyak membaca. Dalam hal ini, salah satu lembaga yang menjadi kebanggaan bangsa tempat menaruh harapan adalah lembagalembaga perpustakaan yang bisa menjadi pusat informasi bagi pelajar dan masyarakat umum. Namun sangat disayangkan, jumlah perpustakaan di Indonesia masih jauh dari target yang diharapkan. Hal tersebut dapat dilihat dalam tabel berikut. 


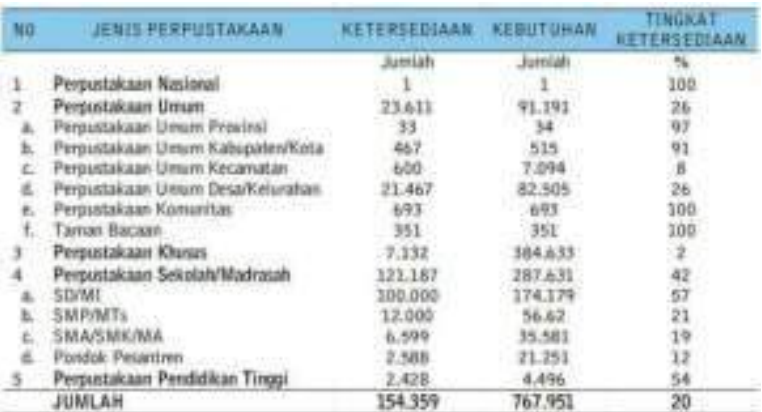

Sumber: LAKIP Perpusnas 2016

Berdasarkan tabel tersebut, dapat dilihat bahwa perpustakaan umum baru sekitar $26 \%$ yang tersebar di seluruh Indenesia. Sementara perpustakaan umum kecamatan baru $8 \%$ dari target yang diharapkan [2]. Bila jumlah perpustakaan saja masih kurang apalagi dengan penyediaan teknologi untuk mengakses bahan bacaan di perpustakaan.

Penggunaan teknologi dalam dunia perpustakaan pada dasarnya bukanlah sesuatu yang asing. Namun kebanyakan, teknologi seperti penyediaan komputer, masih sebatas sebagai perangkat yang digunakan oleh pengelolah perpustakaan. Dari hasil survey dan observasi yang dilakukan oleh tim peneliti IPB, menerangkan bahwa $92.6 \%$ perpustakaan daerah yang ada di Indonesia sudah memiliki perangkat komputer. Itu tahun 2011 [3].

Tahun 2021 dipastikan semua perpustakaan sudah memiliki komputer untuk membantu pengelola perpustakaan mau pun sebagai alat untuk mempermudah pengunjung dalam mendapatkan informasi. Komputer memang sekarang bukanlah hal yang asing lagi. Berbeda dengan vending machine yang berdasarkan hasil observasi online yang dilakukan penulis menemukan bahwa penggunaan vending machine dalam bentuk Anjungan Pengembalian Mandiri di kepustakaan Indonesia baru digunakan di Perpusnas (Perpustakaan Nasiona) RI pada bulan Maret tahun 2021 [4]. Pengadaan mesin ini muncul sebagai solusi simpan pinjam buku di masa pandemi sebagai upaya untuk mencega penyebaran virus melalui buku.

Pada tahun 2006, Progress in International Reading Literacy Study (PIRLS) yang ke dua, hasil yang ditunjukkan menginformasikan betapa rendahnya minat baca anak di Indonesia. Dari hasil survey yang dilakukan pada 40 negara. Indonesia menempati peringkat ke 36 [5]. Sementara di sisi lain sekolah dan perpustakaan terkadang masih belum mengizinkan peminjaman buku untuk dibawa pulang. Bahkan, Perpusnas sendiri baru mengeluarkan peraturan baru mengenai dibolehkannya peminjaman buku untuk dibawa pulang dengan berbagai ketentuan dan persyaratan.

Tujuan utama perpustakaan menyalurkan dan menyediakan buku atau bahan pustaka bagi para pembacanya. Disitribusi buku sangat diperlukan karena syarat wajib agar minat membaca dapat tumbuh dan berkembang yakni dengan adanya buku. Oleh karena itu sirkulasi peminjaman dan pengembalian buku mestinya bisa dibuat lebih mudah sehingga pembaca buku bisa mendapatkan buku yang diinginkan dengan mudah begitu juga dengan cara pengembaliannya. Sehingga pengelola perpustakaan bisa lebih terbantu dan pelajar atau pun masyarakat umum juga bisa mengembalikan buku dengan mudah. Dengan demikian buku koleksi perpustakaan juga bisa tetap terjaga.

Namun, pelayanan itu hanya bisa dinikmati oleh pelajar, mahasiswa, dan masyarakat yang bisa menjangkau Perpusnas, padahal hal yang serupa bisa diterapkan di perpustakaan-perpustakaan daerah maupun perpustakaan kampus. Vending mechine berupa Book Dropbox yang bisa digunakan untuk mengembalikan buku di perpustakaan. Oleh karena itu, penulis tertarik untuk menulis jurnal yang berjudul Penerapan Finite Automata pada Vending Machine dalam Melakukan Transaksi Pengembalian Buku di Perpustakaan.

\subsection{Perpustakaan}

Perpustakaan berasal dari kata dasar pustaka yang berarti buku atau kumpulan bahan-bahan rujukan dan perkakas perangkat lunak [6]. Setelah mendapat imbuhan per- dan -an, dapat diartikan menjadi tempat kumpulan bahan informasi. Sementara dalam istilah bahasa Inggris perpustakaan disebut library yang berasal dari bahasa Latin libre yang artinya buku. Dalam bahasa Jerman dan 
Belanda disebut bibliothek sedangkan dalam bahasa Spanyol dan Portugis bibliotheca [7].

Berdasarkan UUD No 43 Tahun 2007

Pasal 1 ayat 1 , Perpustakaan adalah institusi pengelola koleksi karya tulis, karya cetak, dan/atau karya rekam secara profesional dengan sistem yang baku guna memenuhi kebutuhan pendidikan, penelitian, pelestarian, informasi, dan rekreasi para pemustaka. Diperjelas dengan ayat 2, Koleksi perpustakaan adalah semua informasi dalam bentuk karya tulis, karya cetak, dan/atau karya rekam dalam berbagai media yang mempunyai nilai pendidikan, yang dihimpun, diolah, dan dilayankan [8].

Perpustakaan memiliki pengurus yang bertugas mengelola informasi untuk para pemustaka dan bertanggung jawab dalam hal pelayanan informasi penyajian, pengolahan dan pengumpulan informasi [9].

IFLA (The International Federation of Library Associations and Institutions) mendefinisikan perpustakaan umum, sebagai berikut:

"A public library is an organisation established, supported and funded by the community, either through local, regional or national government or through some other form of community organisation. It provides access to knowledge, information, lifelong learning, an works of the imagination through a range of resources and services and is equally available to all members of the community regardless of race, nationality, age, gender, religion, language, disability, economic and employment status and educational attainment."

Bila diterjemahkan dalam bahasa Indonesia berarti, "Perpustakaan umum dibuat dan dibangun oleh masyarakat melalui pemerintah nasional, provinsi, daerah, atau melalui organisasi masyarakat. Seluruh masyarakat dari berbagai kalangan memiliki hak yang sama untuk dapat mengakses informasi, pengetahuan dan pembelajaran yang tak terbatas." [10]

\subsection{Finite State Automata}

Finite automata adalah mesin abstrak berupa sistem model matematika yang dapat mengenali bahasa paling sederhana (bahasa reguler) dan dapat diimplementasikan secara nyata. Sebagaimana didefinisikan dalam buku yang berjudul Theory of Finite Automata with an Introduction to Formal Languages:

A deterministic finite automaton is a mathematical model of a machine that accepts a particular set of words over some alphabet [11].

Finite State Automata dinyatakan oleh pasangan 5 tuple, yaitu:

$\mathrm{M}=(\mathrm{Q}, \Sigma, \delta, \mathrm{S}, \mathrm{F})$

$\mathrm{Q}=$ himpunan state

$\Sigma=$ himpunan simbol input

$\delta=$ fungsi transisi $\delta: Q \times \Sigma$

$\mathrm{S}=$ state awal / initial state, $\mathrm{S} \in \mathrm{Q}$

$\mathrm{F}=$ state akhir, $\mathrm{F} \subseteq \mathrm{Q}$

$\epsilon$-NFA merupakan salah satu jenis NFA yang transisinya dapat terjadi tanpa input. Sebab, $\epsilon$-NFA memiliki notasi formal yang menyerupai NFA, tetapi hanya pada himpunan input $(\Sigma)$ yang terdiri dari epsilon $(\epsilon)$ [12].

\subsection{Vending Machine}

Vending machine merupakan alat atau mesin elektronik yang digunakan untuk menyediakan dan menjual berbagai macam produk yang dapat dilihat dibalik kaca seperti makanan ringan, minuman, rokok, tiket dan lain sebagainya tanpa bantuan operator atau penjual [13] .

Vending machine di Indonesia banyak beroperasi dengan produk seperti makanan ringan, minuman, rokok, tiket, kopi, produk konsumen, bahkan emas. Dalam hal ini, finite automata dapat dijadikan logika dasar untuk membuat simulasi vending machine [14].

Penelitian yang serupa sebelumnya sudah pernah dilakukan oleh peneliti terdahulu. Berikut ini beberapa penelitian yang menerapkan finite automata pada vending machine untuk digunakan dalam kehidupan sehari-hari.

Salah satu artikel berjudul Desain Vending Machine Rujak Buah dengan Finite State Automata yang dimuat dalam jurnal IJCIT. Berdasarkan artikel tersebut dapat ditarik suatu kesimpulan bahwa perancangan desain vending rujak buah dapat menjadi alternative penjualan produk rujak dengan nilai tambah berupa otomasi, pengemasan dan 
kehigienisan suatu produk yang dapat menarik konsumen secara luas. Selanjutnya pada desain rancangan FSA dalam VM rujak buah ini dapat dikembangkan secara fleksibel dengan tidak terpaku oleh jumlah dan jenis buah yang akan dijadikan sebagai kombinasi rujak buah [12].

Hal yang serupa juga dijelaskan dalam suatu artikel yang berjudul Desain Vending Machine Rokok dengan Mengimplementasikan Finite State Automata Terintegrasi dengan E-KTP. Vending machine menyocokkan usia pembeli dengan database KTP. Sehingga, pembeli dibawah umur tidak bisa melakukan transaksi pembelian dan peredaran rokok pada pembeli dibawah umur dapat terkendali dan semakin berkurang [15].

Hal yang menarik juga dilakukan oleh Rachman dalam artikelnya yang berjudul Finite State Automata Approach for Text to Speech Translation System in IndonesianMadurese Language. Dari penelitian tersebut dapat ditarik kesimpulan sebagai berikut.

The output of the first level FSA becomes input for the second level. The application of FSA in Text to Speech applications is effectively used with accuracy value of $90 \%$. The resulting sound output is in accordance with the results of syllables, but the pronunciation of some translated sentences does not have the correct intonation. The accuracy results of the intonation pattern in pronunciation of the system is $85 \%$ [16].

Artikel berjudul Perancangan Validasi Permohonan Narasumber Pada Sistem Informasi Permohonan Narasumber Menggunakan Finite State Automata juga membahas hal serupa. Hasil penelitian menunjukkan bahwa tahapan validasi permohonan narasumber pada sistem informasi permohonan narasumber dapat menggunakan FSA sebagai dasar logika dengan syarat ukuran dan tipe file, e-mail, dan nomor telepon telah terpenuhi pada tahapan validasi [17].

Penelitian serupa juga sudah pernah dilakukan terkait dengan perpustakaan dengan judul Anjungan Layanan Mandiri di Unit Perpustakaan Kedokteran, Kesehatan
Masyarakat, dan Keperawatan Universitas Gadjah Madah. Berdasarkan hasil penelitian tersebut dinyatakan bahwa adanya Anjungan Layanan Mandiri di perpustakaan dengan menggunakan kartu mahasiswa sangan membantu pelayanan pada mahasiswa. Keberadaan Anjungan Layanan Mandiri tersebut membuat mahasiswa tidak bergantung sepenuhnya kepada petugas perpustakaan dan waktu yang dibutuhkan dalammeminjam, mengambalikan, atau mencari referensi berupa buku pun lebih cepat dilakukan. Meski demikian, masih ada kendala yang ditimbulkan seperti kartu yang tidak terbaca, struk anjungan layanan mandiri yang kadang tidakmau keluar. Hal tersebut tentunya masih memerlukan bantuan dari petugas perpustakaan untuk menyelesaikannya [14].

Selain itu ada juga yang terkait dengan layanan perpustakaan digital di masa pandemic Covid 19. Dapat disimpulkan bahwa layanan literasi digital dianggap cukup efektif untuk meningkatkan minat baca siswa di masa pandemi Covid-19. Hal itu bisa dilihat dari mayoritas siswa lebih senang membaca melalui layanan literasi digital karena banyak informasi yang bisa diperoleh dengan mudah. Namun dalam penggunaan layanan literasi digital di masa pandemi Covid-19 ini juga perlu adanya kerjasama antara orang tua, dan siswa agar aktivitas membaca dapat lebih terarah dan benar [18].

\section{Metode Penelitian}

Tahapan metode penelitian dapat dilihat pada gambar 1, yakni finite state automata, perancangan diagram state, dan desain vending machine.

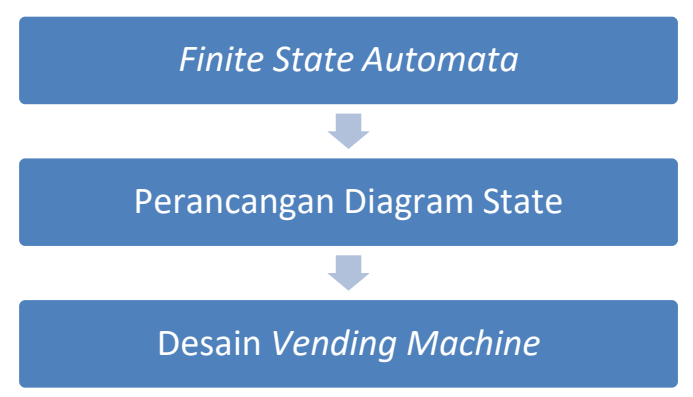

Gambar 1. Metode Penelitian 
1. Finite State Automata yakni melakukan penggambaran FSA menggunakan NonDeterministic Finite Automata (NFA).

2. Perancangan Diagram State, yakni rancangan mengenai fitur-fitur yang terdapat pada VM

3. Desain Vending Machine, yakni melakukan desain tampilan antarmuka saat VM diimplementasikan.

\section{Hasil Penelitian}

\subsection{FSA Vending Machine Pengembalian Buku}

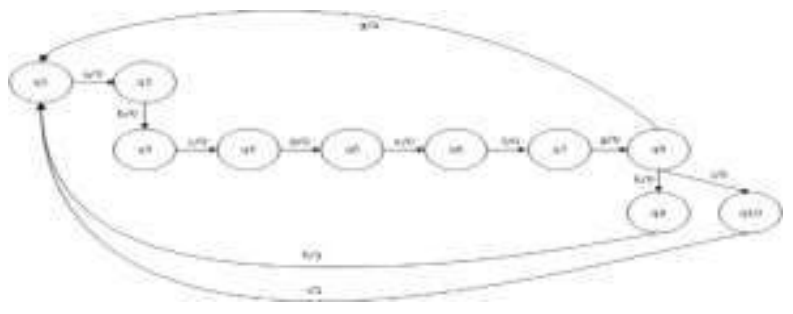

Gambar 2. FSA Vending Machine (VM) Pengembalian Buku

Berdasarkan diagram state di atas, konfigurasi mesin dapat dijelaskan sebagai berikut:

$\mathrm{Q}=\left\{\mathrm{q}_{1}, \mathrm{q}_{2}, \mathrm{q}_{3}, \mathrm{q}_{4}, \mathrm{q}_{5}, \mathrm{q}_{6}, \mathrm{q}_{\mathrm{z}}, \mathrm{q}_{8}, \mathrm{q}_{9}, \mathrm{q}_{10}\right\}$

$\sum=\{\mathrm{a}, \mathrm{b}, \mathrm{c}, \mathrm{d}, \mathrm{e}, \mathrm{f}, \mathrm{g}, \mathrm{h}, \mathrm{i}\}$

$\mathrm{S}=\left\{\mathrm{q}_{1}\right\}$

$\boldsymbol{\Delta}=\{0,1, \mathrm{~h}, \mathrm{i}\}$

Konfigurasi mesin tersebut memiliki beberapa simbol state yang menyimbolkan proses sebagai berikut:

$\mathrm{q}_{1}=$ state awal

$\mathrm{q}_{2}=$ buka pintu

$\mathrm{q}_{3}=$ memindai nomor barcode buku

$\mathrm{q}_{4}=$ memindai judul buku

$\mathrm{q}_{5}=$ memindai tanggal peminjaman

$\mathrm{q}_{6}=$ memindai periode peminjaman

$\mathrm{q}_{7}=$ memindai nama peminjam

$\mathrm{q}_{8}=$ memindai denda peminjaman

$\mathrm{q}_{9}=$ tipe pembayaran denda tunai

$\mathrm{q}_{10}=$ tipe pembayaran denda non-tunai

Konfigurasi diagram state tersebut akan menerima masukan berupa satu dan nol. Jika mendapat masukan nol, maka state akan berlanjut ke state berikutnya. Apabila mendapat masukan satu, maka mesin telah menyelesaikan tugasnya dan
Kembali ke state awal. Diagram state tersebut juga memiliki masukan khusus untuk pembayaran denda tunai dan nontunai.

Pada state awal pemustaka akan diminta untuk menyentuh pilihan buka pintu pada layar VM untuk membuka tempat memasukkan buku yang telah selesai dipinjam, maka state awal $\mathrm{q}_{1}$ akan menuju ke state q2. Saat buku telah masuk di dalam VM, buku akan dipindai dan hasilnya akan muncul pada layar secara berurutan mulai dari nomor barcode buku, judul buku tanggal peminjaman, periode peminjaman, nama peminjam, dan denda peminjaman. Maka state $\mathrm{q}_{2}$ juga berpindah secara berurutan ke state $\mathrm{q}_{3}, \mathrm{q}_{4}, \mathrm{q}_{5}, \mathrm{q}_{6}, \mathrm{q}_{7}$, dan $\mathrm{q}_{8}$. Apabila pemustaka mengembalikan buku sebelum periode peminjaman berakhir, maka pada kolom denda tertulis 0 . Namun, jika pemustaka melewati batas akhir periode peminjaman, maka pada kolom denda tertulis sebuah nominal, misalnya lewat dari sehari maka akan muncul angka 1000, jika lewat dari dua hari maka akan muncul angka 2000, dan seterusnya. Bagi pemustaka yang mendapatkan denda maka akan muncul metode pembayaran, jika memilih pembayaran tunai maka state $\mathrm{q}_{8}$ akan menuju ke state $\mathrm{q}_{9}$ dan diminta untuk memasukkan uang tunai. Namun, apabila memilih pembayaran non-tunai maka state q8 akan menuju ke state $\mathrm{q}_{10}$ dan diminta untuk memindai barcode Qris dengan aplikasi $e$-wallet.

\subsection{Desain Vending Machine}

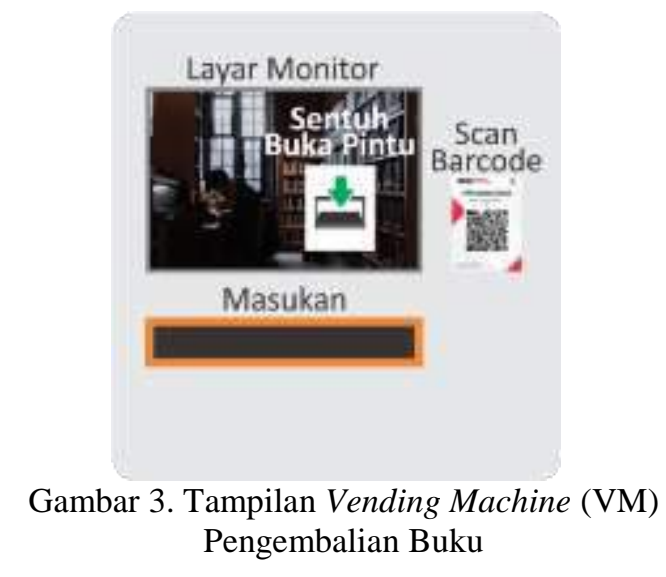


Prinsip kerja VM pengembalian buku yaitu, pemustaka menyentuh pilihan buka pintu pada layar dan memasukkan buku yang telah selesai dipinjam maksimal empat buku. VM memproses pemindaian buku dan hasilnya akan tertera pada layar berupa kolom yang berisi nomor barcode buku, judul buku tanggal peminjaman, batas waktu peminjaman, nama peminjam dan denda keterlambatan pengembalian. Pemustaka yang mengembalikan tepat waktu, kolom denda akan tertulis 0 dan penggunaan VM telah berakhir pada tahap ini. Namun, jika lewat dari batas waktu peminjaman, maka pada kolom denda akan tertulis sebuah nominal sesuai dengan berapa hari dari batas waktu peminjaman. Kemudian, akan muncul pada layar pilihan metode pembayaran, jika memilih pembayaran tunai maka pintu VM akan terbuka dan pemustaka diminta untuk memasukkan uang tunai ke dalamnya. Namun, apabila memilih pembayaran non-tunai maka pemustaka diminta untuk memindai barcode Qris dengan aplikasi e-wallet, jika transaksi pembayaran telah selesai maka pada layar VM akan muncul pemberitahuan bahwa transaksi berhasil.

\section{Kesimpulan}

Berdasarkan konsep Finite State Automata, dapat disimpulkan bahwa penggunaan Non-deterministic Finite Automata pada desain Vending Machine pengembalian buku di perpustakaan dapat mempermudah transaksi pengembalian buku di perpustakaan. Vending machine pengembalian buku memiliki fitur pembayaran denda, fitur ini menggunakan dua metode pembayaran yaitu, pembayaran secara tunai dan non-tunai. Sehingga dapat memmpermudah pemustaka dalam membayar denda karena dapat langsung dibayar ditempat.

\section{Saran}

Saran untuk penelitian selanjutnya yakni perlu adanya pengembangan Vending Machine dengan penambahan fitur pengembalian uang tunai jika pemustaka membayar lebih dari nominal denda.

\section{Daftar Pustaka}

[1] J. C. Irawan, I. M. A. Pakereng, and R. Somya, "Perancangan dan Implementasi Finite Automata pada Simulasi Vending Machine," d'CARTESIAN, vol. 1, no. 1, p. 42, 2012, doi:

10.35799/dc.1.1.2012.534.

[2] Puslitjakdikbud, Indeks Aktivitas Literasi Membaca 34. 2019.

[3] F. Zuhrah, "Pentingnya Teknologi Informasi Dalam Meningkatkan Pelayanan Di Perpustakaan," J. Iqra', vol. 5, no. 1, pp. 40-49, 2011.

[4] Y. Ardhi, "Perpusnas Gunakan Mesin Pengembalian Otomatis," Republika, 2021.

https://www.republika.co.id/berita/qqdnb 0314/perpusnas-gunakan-mesinpengembalian-buku-otomatis-3.

[5] I. Syarif and E. Elihami, "Pengadaan Taman Baca Dan Perpustakaan Keliling Sebagai Solusi Cerdas Dalam Meningkatkan Minat Baca Peserta Didik," Maspul J. Community Empower., vol. 1, no. 1, pp. 109-117, 2020.

[6] KEMENDIKBUD, "KBBI ONLINE." https://kbbi.kemdikbud.go.id/entri/Perpus takaan.

[7] A. R. Saleh, "modul 1 Manajemen Perpustakaan," pp. 1-45, 2014.

[8] UUD No 43 Tahun 2007 Pasal 1, vol. вы12у, no. 235. 2007.

[9] Sub, "Perpustakaan Digital," Pustak. Perpust. UM, vol. 10, no. 2, pp. 1-11, 2009, [Online]. Available:

http://library.um.ac.id/images/stories/pust akawan/kargto/Perpustakaan Digital.pdf.

[10] IFLA, "IFLA Public Library Service Guidlenes," C. K. and B. A. B. Gubbin, Ed. 1390, p. شماره 8; ص 117-99.

[11] D. D. E. Long and S. Cruz, Theory of Finite Automata with an Introduction to Formal Languages Theory of Finite Automata with an Introduction to Formal Languages, no. January 1989. 2016.

[12] R. A. Nugraha, A. Mulyani, and W. Gata, "Desain Vending Machine Rujak Buah Dengan Finite State Automata," IJCIT (Indonesian J. Comput. Inf. Technol., vol. 5, no. September, pp. 198-207, 2020.

[13] T. H. Wicaksono, F. D. Amrizal, and H. A. Mumtahana, "Pemodelan Vending Machine dengan Metode FSA ( Finite State Automata )," DoubleClick J. Comput. Inf. Technol., vol. 2, no. 2, pp. 
66-69, 2019, [Online]. Available:

http://e-

journal.unipma.ac.id/index.php/doubleclic

$\mathrm{k}$.

[14] E. Erni, F. Titiani, S. A. Putri, and W.

Gata, "Penerapan Konsep Finite State

Automata Pada Aplikasi Simulasi

Vending Machine Jamu Tradisional," $J$.

Inform., vol. 7, no. 2, pp. 141-147, 2020,

doi: $10.31294 /$ ji.v7i2.8151.

[15] A. Faisal, G. V. Saragih, and W. Gata, "Desain Vending Machine Rokok Dengan Mengimplementasikan Finite State Automata Terintegrasi Dengan E-KTP," Matics, vol. 12, no. 1, p. 55, 2020, doi: 10.18860/mat.v12i1.8693.

[16] F. H. Rachman, Qudsiyah, and F. Solihin, "Finite State Automata Approach for Text to Speech Translation System in Indonesian-Madurese Language," J. Phys. Conf. Ser., vol. 1569, no. 2, 2020, doi: 10.1088/1742-6596/1569/2/022091.

[17] F. Said, D. Andriyanto, R. Sari, and W. Gata, "Perancangan Validasi Permohonan Narasumber Pada Sistem Informasi Permohonan Narasumber Menggunakan Finite State Automata," Paradig. - J. Komput. dan Inform., vol. 22, no. 2, pp. 189-196, 2020, doi: 10.31294/p.v22i2.8157.

[18] D. R. Wulandari and M. Sholeh, "Efektivitas Layanan Literasi Digital Untuk Meningkatkan Minat Baca Siswa Di Masa Pandemi Covid-19," J. Inspirasi Manaj. Pendidik., vol. 9, no. 2, pp. 327335, 2021. 